\title{
Agency and Subjectivity in Pandemic (Neoliberal) Times: A Duoethnografic Study
}

\section{Agência e subjetividade em tempos (neoliberais) de pandemia: um estudo duoetnográfico}

Lívia Fortes*

*Universidade Federal do Espírito Santo (UFES), Vitória, Espírito Santo / Brasil lifortes34@gmail.com

https://orcid.org/0000-0002-1765-0531

Luciana Ferrari**

**Universidade Federal do Espírito Santo (UFES), Vitória, Espírito Santo / Brasil luferrarioliveira2019@gmail.com

https://orcid.org/0000-0003-3427-0474

\begin{abstract}
This duoethnographic study addresses some of the conflicts that two academics in a public Brazilian University have experienced during pandemic times. As they engage in conversations prompted by their own narratives exchanged online during the first weeks of quarantine, they start theorizing on some emerging topics that, for them, needed to be critically examined and, eventually, ressignified. In this sense, this article discusses the role of agency in their academic and personal lives and how it was engendered during such complex and unpredictable times, drawing special attention to questions of collectivity and diversity. Furthermore, the present work examines questions of identity and the neoliberal subjectivities that also emerged through this extremely rich collaborative experience, leading, therefore to risky and truthful subjectification processes on the part of the authors.
\end{abstract}

KEYWORDS: duoethnography; agency; neoliberalism; subjectification.

RESUMO: Este estudo duoetnográfico aborda alguns dos conflitos que duas docentes em uma Universidade federal brasileira vivenciaram durante a pandemia. Ao se engajarem em conversas induzidas por narrativas trocadas virtualmente durante as primeiras semanas da quarentena, as autoras iniciam teorizações acerca de temas emergentes que, para elas, careciam de análises críticas e posterior ressignificação. Nesse sentido, o presente artigo discute o papel da agência em suas vidas pessoais e profissionais e como ela foi engendrada durante tempos tão complexos e imprevistos, voltando-se para questões de 
coletividade e diversidade. Ademais, este trata de questões identitárias e de subjetividades neoliberais que também emergiram durante esta rica experiência colaborativa, levando, portanto, a processos subjetificadores arriscados e verdadeiros por parte de suas autoras.

PALAVRAS-CHAVE: duoetnografia; agência; neoliberalismo; subjetificação.

\section{Introduction}

The challenges that the Covid-19 pandemic have imposed on our human condition as sociological subjects, that is, as sociocultural and historical individuals constituted by language and by social structures and interactions, are innumerable and of different natures. Many are the decenterings and countless are the uncertainties that our identities and academic praxis have undergone and been subject to. In the face of so many changes and the countless questions implicated in them, we are urged to act with responsibility, ethics and critical awareness as the pandemic has strongly highlighted and reinforced social differences and, alongside, our weak capacity to deal with the different other, the unpredictable and the risk.

We have no recipes, no survival kits or manuals, and never before has the motto "tomorrow is another day" been so true. Along with Paulo Freire (1987, p. 72), the crisis of the new Coronavirus reminds us that we are unfinished, imperfect, inconclusive beings, inserted in a reality that, "being historical as well, is also unfinished". ${ }^{1}$ Thus, the Covid-19 pandemic has made history. We do not know when the virus will cease to spread, if it ever will, nor how transformed we will eventually be. Therefore, assuming our imperfections and accepting the fragility of the other and of our institutions has never been more urgent and necessary, as well as the understanding that we are part of that too and can, if we wish, transform our own realities or at least, the way we want to see them. All of that constitutes a survival exercise as well as an exercise of citizenship, new language practices, new subjectivity events that lead us to Freire's (1987, p. 73) timely understanding "in order to be, one has to go on being".

Based on these brief and initial reflections on the pandemic, this work ramifies and is scientifically and identitarily instituted through the writers' subjectivities in the making. In this duoethnographic study, two women,

\footnotetext{
${ }^{1}$ All the quotes originally published in Portuguese have been translated by the authors.
} 
academics, teachers, mothers, friends and life partners inside and outside the University focus on their own and multiple lifeworlds influenced by the experiences and transformations that the new Coronavirus brings to our personal and professional lives, to the institutions we attend, to our discourses and social practices. Our collaborative interactions mediated by technology in times of social/physical isolation, along with our personal accounts on our first experiences, as well as our anxieties and actions during the first months of the pandemic became triggers for deeper critical reflections and deconstructions, ruptures and agency which, for us, have turned into rich subjectification processes.

In the following lines, we invite the reader to embark with us on this route of problematizations and ressignifications around notions of agency and subjectivity influenced by the neoliberal ethos in pandemic times. Through our anxieties and the conflicts emerging from our discourses, we share a little bit of our learnings as we also open ourselves to the risk and unpredictability of the meanings underlying this article, bound to the multiple interpretations that will, in turn, represent the subjectivities of our readers. But for those who have apparently survived the threats of the disease, may this new challenge come!

\section{Methodology}

As we set out to outline the possibilities for writing this article about language education in pandemic times, one very thought crossed our minds as we wanted our contribution to this special RBL $A$ issue to be both valuable and personal. How could our views be juxtaposed and analyzed dialogically based on our personal experiences as academics (teacher educators at a Brazilian Federal University), as the mothers of children attending both elementary and middle private Brazilian schools, as upper-middle-class women, as daughters and friends, to name a few of the identities that we hold?

Having developed our academic praxis upon the QualitativeInterpretative research paradigm (ERICKSON, 1986), with special emphasis on postmodern and poststructuralist views and epistemologies, we found that the duoethnography perspective could meet our needs as, according to Sawyer and Liggett (2012), 
[d]uoethnography as a method is more conceptual than prescriptive. Its method is framed by a poststructuralist approach to research. Such an approach rejects the notion of a single, fixed, and absolute reality existing independently of human consciousness and imagination. Instead, meanings are constructed in the process of interpretation. Drawing from this philosophy, duoethnographers engage in multiple interpretations as they use self as a site of analysis of sociocultural meanings and influences (SAWYER; LIGGETT, 2012, p. 629).

Furthermore, the highlight of duoethnography may be that it allows researchers to review their past experiences and the meanings attached to them through dialogue, and, as they engage in conversations (be it spoken or written), new insights arise providing new opportunities for ressignification. As stated by Lowe and Kiczkowiak (2016), this type of investigation is not about the researchers per se as it should not be "simply" autobiographical. What it does is to frame researchers' perspectives on certain topics and inquiries as they represent the site, or the loci, where meanings are located and eventually, reconceptualized. According to the same authors,

[t] his emphasis on the subjective and individual forms the basis of duoethnography, since it seeks to circumvent the crisis of representation in qualitative writing (the difficulty in authentically representing the voice of another person or group) by allowing people to present and explore, through dialogue, their own experiences (LOWE; KICZKOWIAK, 2016, p. 4).

In a more recent attempt to overcome the "crisis of representation" mentioned above, Morgan, Martin and Maciel (2019, p. 10-11) highlight the nature of duoethnography as being "[...] less concerned with arriving at singular, objective truths and more concerned with exploring how other participants and stakeholders may be differentially positioned and effected by specific policy and practices." Upon their reasons for choosing this approach they advocate for the possibility of juxtaposing different perspectives on common phenomena by allowing “[...] co-authors to see our own localities of research and teaching in ways less considered", betting on the richness of the "pluralization of experience" (MORGAN; MARTIN; MACIEL, 2019, p. 10-11). 
Resuming the central theme of this article, we acknowledge that the dynamic nature of the pandemic has definitely impacted people's lives in quite similar, but yet, unique ways. As we seek to explore some of our experiences and emotions through the narratives we brought about and chose to represent us in the course of quarantine days, and mostly, taking into account the complex and rhizomatic nature of our identities inside and outside of the academic realm, the duoethnography method seems to be more than suitable to the present account. Following Sawyer and Liggett (2012), through duoethnography, as researchers and co-authors, we do not need to avoid being implicated in the data and in the meanings drawn from them as

[i]nstead of "bracketing" themselves out of the method, duoethnographers situate themselves centrally within the meaning of the text they are creating, thus promoting the inquiry goal of researcher/reader self-reflexivity. As an aspect of social justice, reflexivity in this instance is a process of deep researcher reflection and conceptual and behavioral change. A goal in duoethnography is not to "uncover findings," but rather to promote more complex and inclusive social constructions and re-conceptualizations of experience (SAWYER; LIGGETT, 2012, p. 630-631).

In terms of procedures to attend to, Rose and Montakantiwong (2018) list some general tenets within any duoethnographic study: 1 . It must be dialogic, with narratives juxtaposed and collaboratively explored; 2 . It should allow the authors to challenge one another within their interpretation frames as well as readers to be challenged to actively make their own meanings; 3. It invests on the strength of plurality in views as differences, and 4. Its methodology must avoid being too prescriptive so as to remain open and flexible. As far as reliability is concerned, we agree with the idea that "In duoethnography, research becomes trustworthy when researcher reflexivity becomes apparent, when the research is explicitly tied to human life and researcher experience” (SAWYER; LIGGET'T, 2012, p. 630).

Having all this in mind and after agreeing upon what procedures we would like to follow for the present account, we have each written our narratives on the pandemic and then shared them so that we could make our own meanings while reading them and, consequently, engage into a collaborative and dialogic exercise. That exercise presented itself as a 
challenging one: firstly because it was the first time we had ever worked with a duoethnography; secondly, because we felt each other as being the research site indeed, that is, our identities were "on the spot" for anyone to "grab" them, which can be an uncomfortable situation; thirdly, because it was a rhizomatic process, meaning we did not know or plan what was about to come, since the themes would emerge as we would read and reflect upon each other's comments on both researchers' narratives.

In the next section we will present excerpts of both narratives, produced and exchanged online as the pandemic did not allow face to face conversations and gatherings. We start with Luciana's narrative, The Pandemic and I, moving on to Livia's narrative, Covid-19 Narratives, both followed by the flows of online conversations that were generated. Following them, we present a critical reflection on the emergent themes where we eventually deepen the analysis of the narratives. For organizational (and scope) purposes, we could not present the narratives as a whole, so we picked the exchanges which seemed to have brought about a greater investment from us, the researchers, showing more of our contrasts and differences of opinions. Finally, as it will be noticed below, the excerpts come with some stretches in bold, meaning that they served as prompts and triggers for the comments and the interactions that follow them. This should not mean that the non-highlighted text is not relevant. However, for scope reasons, they will be left for further analysis and critique.

\section{The narratives}

\section{Excerpt 1 (from The Pandemic and I - Luciana)}

One week of joy soon switched to a second week of anxiety and desperation. The school started sending lots of homework activities to be done at home and the logistics was: the school would send the activities to my email address, I would have to print all of them and then send them back to school on a due date, which, for me, represented a total of more than 50 sheets to be printed, scanned one by one and then sent to school! I, then, as an educator and researcher in the Applied Linguistics field, focusing on Literacies, started criticizing the school. What are they doing? Simply transferring the physical world to the virtual one? What about the affordances of the virtual world (KRESS, 2003)? What about the digital epistemologies ( COPE; KALANTZIS 2000)? And the 


\section{digital literacies (COPE; KALANTZIS 2000)? Will my kids (and I) be exposed to "old wine in new bottles" (LANKSHEAR; KNOBEL, 2003)? Or will they be encouraged to make different meanings? Can't they be exposed to the "learn by doing", epistemologies of performance (LANKSHEAR; KNOBEL, 2003)? Or will the school ignore all this pandemic context and simply present the regular content from an analogic perspective/epistemology?}

\section{Luciana and Lívia's interactions}

Lívia: I see your point... it could have been wiser to think of that as just the beginning of a transition, necessary for the time being, and, as everything in life, adjustments, adaptations and improvement would follow. But yes, anxiety blurs our views and instincts, right? As you were ahead in the discussions and epistemological notions of literacies, you probably wanted to see all that "suddenly" take place, but it takes time, right? We, ourselves, did need some time to process all the novelty about Literacies after we had our first contact with the theories. And we could have quit!! You could have refused to print all those sheets... Agency x Subjection?

Luciana: I don't know. I think it was more like some sort of disappointment to see that schools, in spite of the fact that technology has been within their agenda, have not yet considered the digital epistemologies. I agree that it takes time. I guess I was (am) being naive so as to think that these epistemologies have been part of teacher education programs. To tell you the truth, I don't even know if private schools have or provide a teacher education program. That is something I would like to know about.

My agency at that moment was to send an email to the school coordinator explaining why I thought the making of so many copies did not make sense. I also mentioned digital epistemologies and made myself available for help. Some subjection occurred because I did not want to sound like the boring mother-educator person. Plus, the kids learned fast how to make copies and scan their tasks, which was a relief! Then, I decided to give the school some more time to see if the logistics would change. And fortunately, it did!

Thinking of subjection again, I guess it is part of the game, meaning that sometimes we become part of the "system". 
The important thing, though, is to always be aware of the fact that you are in it to critically think about it and contribute to its transformation (when you think it is necessary).

I usually say that when educators become mothers, they suffer. As a mom-educator who has been developing studies on education epistemologies and critical teacher education, I have to confess that I have been very much worried about the quality of the teaching/learning process provided to my triplets (and to other children in general). It came to a point when my husband told me to "choose my fights" because I had been "suffering" a lot with some of the decisions made by the school. All of this to say that sometimes I decide for subjection in order to be a "normal" mom and to suffer less (because the suffering is still there). I consider this "suffering" as a trigger for agency. It is a necessary suffering! And this necessary suffering reminds me of Biesta when he talks about education as a beautiful risk, of Todd, when she tells us that education is imperfect, of Lynn Mario and Walkyria, reminding us that education is a conflictual process... That makes a lot of sense to me!

I have to say that my sufferings have turned out to be trials of agency and most of the times I have been able to transform some of the school decisions, thoughts, generalizations... The sense of relief and happiness that comes after the suffering is indescribable and very intense. A wonderful feeling of contribution to society that makes me proud of being a momeducator, and not a "normal" mom. Boy, have I reflected upon this topic! Thank you for your question!

Lívia: Wow!! Your agency is so powerful and resilient. I have been feeling so powerless and all this pandemic process has even made me consider my choices, motivations and investment as an educator. As a mom, I am ok with the practices I have been observing specially because they have happened and evolved. What kinds of risks am I willing to take? What fights are worth fighting for at home and at work?

\section{Excerpt 2 (from The Pandemic and I - Luciana)}

The ideal school world had been pictured by me, but there was a tiny little detail: we were in the middle of a pandemic, which struck us all of a 
sudden, not leaving time for things to be prepared in advance. The fact emerged. Neither teachers nor their students had been prepared to deal with the unknown in such a fast manner. At the same time, I thought, how come digital epistemologies are still unknown? Researchers have been long talking about the transition from the analogic mindset to the digital one (KRESS, 2003; CASTELLS, 1999), especially when considering globalization and the Internet.

\section{Luciana and Lívia's interactions}

Lívia: Exactly! No one was prepared! Unpreparedness is a key idea for everything we have been experiencing during such unpredicted times, so, we were not prepared, schools were not prepared, the world was not prepared... Last night I listened to Homi Bhabha talking about how unprepared we were, we are... so insightful...

Luciana: Yes, we were not prepared. I was not prepared for a pandemic and having to stay isolated at home with my kids. But I also think that it is very easy to say simply that we were not prepared... I don't know... and I am thinking of this as I write it now... it seems that we don't want to take responsibility for the bad things that have been happening. No, we were not prepared for a pandemic and maybe had no idea of what it was, but we have been "prepared" for what has become more evident together with the pandemic: social injustices, digital exclusion... Take global warming for example. If something really bad happens, can we say that we were not prepared? I think time has been giving us some hints of what is to come and I also think that we have been ignoring these hints... I don't know. It is as if the problems we have are too distant from us or have nothing to do with us. Social injustices? Thank God I have a house to live in and food on the table. Public schools? Thank God I have the money to provide private education to my children. This is what I hear out there. People don't care about social injustices... people don't wanna take responsibilities, they don't wanna fight for public policies that solve such problems... At least may our "unpreparedness" now serve as food for thought for present and future transformations.

Lívia: Yes, just as we have not thought of digital epistemologies and literacies when we redesigned our curriculum in spite of all our 
awareness of them, their relevance to education in general terms. We don't have a single subject designed for that purpose... Cause digital literacies are also about dealing with the unknown, relying on intuition, trial and error... And at the same time, they embody a whole discussion of social inclusion, exclusion, injustice, inequality... I guess I am taking responsibility here for being unprepared, right? Just as the University and Governments ought to take responsibility, be held accountable or not. And this makes me think of neoliberal policies, mindsets and governments that have increasingly judged our "unpreparedness" so as to avoid seeing and dealing with the huge complexities and inequalities present in our work environment.

\section{Excerpt 3 (from The Pandemic and I - Luciana)}

Regardless of all this, the government has been pushing the Universities to start their classes remotely or on site. In the meanwhile, more and more people have been contaminated and dying! I keep thinking of the outrage of starting remote classes when there is no plan from the government or even from the University presidency showing how digital inclusion will be made! Some will say that the majority of students have the means to start studying remotely immediately and that they cannot pay for the injustices that surround the others. Well, this makes me think of (1) what Menezes de Souza (2011) calls collective ethics and of (2) Arendt's (2014) idea that we only exist within a collectivity. Not one person can be left behind! I think it is more than time for people to fight for their rights/needs together! People who have been suffering from social inequalities have been silenced for too long in our country and it is a shame that they have had to fight for themselves, not being able to count on the "other side of the line" (SOUSA SANTOS, 2010) people. Up to when will they be silenced and ignored?

\section{Luciana and Lívia's interactions}

Lívia: I said that, and I remember you saying all of this! I see your point, but I don't see it only... Am I too immersed in neoliberalism? Am I empathizing too much with so many teachers all around us that have been putting all their efforts so as to make things happen? Am I neglecting the learners who do not have the means to carry 
on? Cause, I feel "safer" seeing my kids carry on with their classes so that I can carry on with my work... had no one been given the chance to carry on, I'd be ok with not doing anything...

Luciana: I think that the efforts teachers have been making have been treated in a very "romanticized" way. Yes, they have been making a lot of effort, but have also been forced to do so! Choice has not been given to them. They are most of the part employees in private schools and the pressure from their bosses and children's parents is enormous!!! We have been seeing lots of parents complaining about teachers and schools right now, and some of the children, especially the very young ones, have quit school because parents don't see the point in paying for education when "real teaching" is not happening. Some teachers, even though making huge efforts, have had their salaries decreased. And some have been fired!

As for the public state schools here, the beginning of remote teaching has not taken the teachers' opinions into consideration. It was a top-down decision, which has been causing a lot of problems to teachers and students. Access to computers and the internet is just one of the problems.

I also feel good that my kids are having classes, after all they have been studying at a private school since forever! Have I been worried about the conditions of public schools? I am not considering the pandemic moment only when I say that... Has society been worried about public education? Really, sometimes I do ask myself if private education should exist... I even question myself why my kids are not studying at a public school! The sides of the line Sousa Santos talks about are indeed very much separated. I wish I could contribute at least to its proximity.

Lívia: Ok, I agree. They have not been heard but I'd like to know their opinions about the process: would they have preferred to wait until the pandemic ceased (and we know it's not gonna go away like this) or are they happy with the "progress" they achieved? I am not romanticizing "progress" here cause we knew this was necessary, it would come some day... I'd rather see progress through these lenses. Ok, the environments were not ideal, but isn't education supposed to be risky? On the other hand, I think it is very sad that education has become this market and that 
school owners could not stop making their profits at a time when so many of us are being financially affected as well. Of course, teachers preferred taking those risks than losing their jobs, but what else could be done in a country where public education has never been a priority, where education policies are not continued, where politicians steal money from education funds and budgets? I guess much of my disappointment and lack of resilience lie there...

Luciana: It is not about preference. It is about not having an option...

\section{Luciana and Lívia's interactions (related to the second stretch in bold from excerpt 3 above)}

Lívia: Yes, I agree, and I see a lot of sensitivity and humanity in these thoughts, but in the neoliberal world we've been living, people would say: "If they really want, they will find the means", which ends up reinforcing meritocracy and entrepreneurial values. I don't really agree with that and I think that is really sad, especially for our country, where social inequality is so huge, as you have pointed out as well. Still, I'd like to see hope, some kind of compromise between neoliberal and "non-neoliberal" discourses and subjectivities as there seems to be no going back... I would like to think of ways in which we could be complicit and still critical... not abiding totally to neoliberal values but denying them and their existence puts us in bubbles...

Luciana: I don't see the bubbles you see.... I see an opportunity to change from the crisis (the pandemic being the crisis now). And when I say change, I am thinking of Foucault's micro politics: change within our localities.

\section{Excerpt 4 (from Covid 19 Narratives)}

The first interactions were very scarce, many students visited the blog but very few posted comments. I thought that, perhaps, the texts posted in English could be too challenging as well as the reflections they incited, in addition to the writing in English that, for many, could be a cause for apprehension, especially when registered and "posted" in a digital environment. So, after my sixth post (after the 4th week the blog was 
created), having no comment or feedback from the students, I decided to quit my initiative. In order to better understand what was happening, I did a second survey to find out what could be hindering students' interaction. And that's when I realized that the complexity of my students' home contexts and their loci of enunciation could not have been overlooked, even though, at first, they had stated their interest in the interaction proposed. Obviously, when I took up the challenge, I thought I was backed up by the desires of my students, as well as paying attention to their specificities. However, what could I have expected from them, many coming from low privileged socioeconomic communities, trying to connect through smartphones and unstable internet, and even more so, experiencing so much anguish, emotional and financial instability, taking care of relatives, children and even patients in their homes, with limited-space homes that may not favor concentration for their studies?

\section{Lívia and Luciana's interaction}

Luciana: It seems that we needed to live a pandemic to be more aware of the importance of getting to know the real specificities of our students: their context of living, their identities, subjectivities... These need to be included in any educational process. The first critical literacy exercise is to really (not superficially) get to know the diverse and heterogeneous context of our students. Don't we say that Discourses "construct" us? Which Discourses have been constructing our students' (and teachers') subjectivities, identities, realities? In education, we talk a lot about teaching content from what students already bring to class. Have we been REALLY doing it? Have we been taking their realities into consideration? Or have we just been pretending to do it? Or doing it superficially? The vulnerability and social responsibilities of our students may be constant and not characteristic of the pandemic moment we have been living now. The process described by you and the reflections upon what you found out are very rich! You took action and that action made you understand many other things that you might not have learned if you hadn't taken action!

\footnotetext{
${ }^{2}$ Gee (2012) defines Discourses (capital D) as ways of being in the world through language, this being endowed with ideologies and beliefs that constitute our social identities.
} 
Lívia: Totally agree! Taking action is risky, subjectification is risky, we never know how our beginnings will be taken by others, right? I like that reflection!

\section{Critical Reflection}

In this section we present our analysis of the excerpts and conversations by providing some theoretical background of the two main themes that emerged: Agency and Subjectivity. As will be noted, both themes are discussed within the realm of neoliberalism and its effects on formal education and on the identities and subjectivities of the participants involved.

\subsection{Agency}

That we are socio-historically constructed beings, shaped by the cultures endowed with ideologies, languages, concepts, moral and ethical values that surround us is well known. That these Discourses (GEE, 2012) influence our practices and build our ways of thinking and acting is also well-known. However, this does not correspond to an immediate incapacity to act, transform and reconstruct our meanings. The pandemic has certainly brought new Discourses to our lives and has triggered reflections and transformations.

Fairclough (1992) states that even though we are shaped by ideologies, we are also able to act creatively in order to make our own connections between the various language practices to which we are exposed and to restructure and reconstruct our meanings within and beyond them. Our capacity to act is also discussed by Lankshear and Knobel (1997) when they state that "individuals are not merely able to participate in some existing literacy and make meanings within it, but also that, in various ways, they are able to transform and actively produce it" " 1997, p. 11). Accordingly, Arendt (2014) states that action is inherent to the human being by saying that it constitutes one of the pillars of the human condition, together with labor and work. ${ }^{4}$

\footnotetext{
${ }^{3}$ Emphasis added.

${ }^{4}$ For Arendt (2014), labor corresponds to the biological process of the human body, and work corresponds to the artificiality of human existence. Action, labor and work are part of what she calls vida activa.
} 
The first trigger to agency found in the interactions was Luciana's critical awareness, which seems to have caused a feeling of anxiety and restlessness towards what she thinks was an inadequate way of introducing remote teaching (described in excerpt 1). This feeling of anxiety and "suffering", as Lucianasays, seems to be justified by the fact that she has been engaged with critical literacies for some time now and, therefore, as Livia says, she has "been ahead in the discussions and epistemological notions of literacies". Luciana's critical awareness triggered her feeling of discomfort and urged her for agency, following Lankshear and Knobel's (1997) idea that critical awareness of the Discourses that surround us is crucial for agency.

Luciana's posture in relation to school norms has revealed itself as a certain kind of "critical" subjection. That reflection emerged in the discussion because of Livia's provocation regarding Luciana's attitude, one of subjection to the school norms or one of agency? For that, we would like to refer to Bourdieu's (1996) ideas of complicity and critique when he analyzes and criticizes scientific discourse. According to the author, in order to deal with the "truths" of scientific discourse, one needs to behave either as an accomplice of it, contributing to the maintenance of the status quo, or as a critical subject, questioning and problematizing it, acting through discourse. It follows from that that one's behavior will depend on his/her understandings of the reality presented to them. In our interactions about excerpt 1 , subjection, in this case, obeying the making of copies demanded by the school, would be seen as complicity to the system, contributing to its maintenance and reinforcing the authorized discourse of the institution. Critique, on the other hand, would be related to Luciana's agency towards the possibility of change, showing resistance to such a discourse. Her response saying that subjection is part of the game does show some complicity. However, as she says, "The important thing, though, is to always be aware of the fact that you are in it to critically think about it and contribute to its transformation (when you think it is necessary)". This is the way she expresses her agency as a result of her critical awareness. The same interaction will be addressed in the next section in identitary terms, highlighting how subjection is also, and always, constitutive of processes of identity construction.

Bhabha (2020) offers a great reflection on unpreparedness, which we understand here as being the second trigger for agency found in our interactions. He sees unpreparedness as a necessary part for agency. 
According to him, "the panicky moment of unpreparedness might prepare one to live up the responsibility of taking action under pressure and making decisions in relation to risk". He adds that unpreparedness "may appear to be a pre-political moment in the life of the subject and the citizen but may also be a quality of time necessary in the midst of flux and fire to decipher an ethical predisposition that leads to deliberate action". The suddenness of the pandemic and the necessary "before-action" feeling of unpreparedness has led to school agency as for the beginning of online classes in private schools. However, we cannot ignore the neoliberal world we live in and the fact that education (and knowledge) has become a commodity, which will be discussed in the next section below.

In excerpt 2, Luciana soon recognizes the school's right for unpreparedness, especially due to the suddenness with which the pandemic struck us all. While Luciana still questions such unpreparedness in times when teacher education has widely debated digital epistemologies, Lívia takes responsibility for being unprepared herself, reminding Luciana that we, as teacher educators (and curriculum designers), have not transformed the course curriculum, when we had the chance, so as to guarantee in it a special slot to digital epistemologies. By reading our narratives and interactions, we may come to the conclusion that, even though we have been debating digital epistemologies, being prepared and truly changing our education is far more complex. Luciana, even though not expressed in her responses to Livia's questions, understands, when analyzing the interactions, that she is not prepared either for the implementation of digital practices and may only be aware of it now, triggered by a crisis. Lankshear and Knobel's (2003, p. 173) performance epistemology, of knowing "how to proceed in the absence of existing models and exemplars", makes a lot of sense now.

At the same time that Luciana seems to acknowledge unpreparedness, in the interactions that follow excerpt 2, she understands that "being unprepared" may also work as an excuse for one not to take responsibility over things and actions. In that sense, Bhabha (2020) problematizes unpreparedness by asking, "what does it mean to be unprepared for something that has been happening for a long time?". Digital exclusion, as mentioned in excerpt 3 , has been a huge issue in our University for a long time, not only now with the pandemic and remote teaching. Can they just say they were not prepared? Unfortunately, what happens is that these social problems "are quickly absorbed into normative narratives of cause and 
consequence, reason and risk, symptom and structure" (BHABHA, 2020). We just hope that the pandemic will serve as a wake-up call so that society does not naturalize these problems anymore.

In the interactions that followed excerpt 3 , the relation between agency and collectivity emerged. While Luciana understands her role as a professor not to adhere to remote teaching unless the government and the University provide digital access to all the students, as stated in excerpt 3, Lívia seems to interpret that as ignoring the neoliberal world we live in, even though she does not agree with its ideologies. She understands such a behavior puts the University into bubbles, into a utopic scenario, distant from real life and, therefore, chooses to be complicit to it. Luciana, on the other hand, by saying that "not one person can be left behind" (excerpt 3) sees it as an opportunity for action, for change, for pressuring and forcing institutions to act from the standpoint of collectivity, diversity and inclusion, corroborating Menezes de Souza's (2011) call for a new ethics, where he understands that "listening to ourselves listening" is key to the transformation and the reduction of the violent conflicts we have been experiencing in the world. As Bhabha (2020) says, "... a capacity to be engaged in the ethics of mutual understanding in equality and to be committed to the modest art of listening and learning from cultures of difference and disadvantages, ... these two qualities are the beating heart of the democratic experience".

As for the private and public-school teachers' agency, society has been celebrating it using the discourse of reinvention, as mentioned in our interactions following excerpt 3. It is important to say that they have not had the choice to be critical, to mention Bourdieu once more, but only accomplices to the system. They are embedded in power relations they may not know they are. If they do, how can they act otherwise? Losing their jobs? We are all neoliberal constructs and, by celebrating their agency without awareness of the difficulties and vulnerable conditions they are in, we are all complicit to the system. The interactions from excerpt 3 lead to a reflection that, even though Luciana sees herself as not subjecting to the school system, isn't she an accomplice of the neoliberal school system when she agrees with their children studying remotely when teachers haven't had the choice to do otherwise? Aren't we all complicit to that status quo?

${ }^{5}$ Taken from the translated version (unpublished) of Menezes de Souza (2011). 
The call for a new ethics, be it a critical literacy ethics (MENEZES DE SOUZA, 2011) or a Subjectivity one (BIESTA, 2014), is a cry for the understanding of the sense of responsibility that one must have to the other. That call seems to be dealt with in our interactions following excerpt 1 and 2 , and in excerpt 3 and its interactions. Luciana reinforces her desire for collectivity referring to Arendt (2014), who says that the existence of humanity is conditioned to its plural collectivity. According to her, collectivity makes us political beings who, by taking action, have the capacity to create history. Action, according to her, is conditioned to plurality, meaning that we are not alone in this world. She reminds us of the dependency we have on each other and that without that dependency, one is never free. Collectivity and freedom are connected.

These were some of the reflections we made regarding how agency is understood, exercised and triggered within our narratives. The next session will deal with the constitution of our subjectivities. In pandemic times, when our identities have been put in jeopardy, any attempt of agency seems to be even riskier.

\subsection{Subjectivities}

In view of the numerous challenges that the New Coronavirus has imposed on our lives and identities, some of them reported on the narratives excerpted above, we see in the Post-modern discourse an anchoring point to understand that identities are constituted in and through the complexity of the world, history, relationships and language, by processes of fragmentation and (re)construction, in constant dynamics arising from crises, displacements or "decenterings". Based on this view, we may now deny the notion of the centered and, therefore, sovereign, autonomous subject, a notion that does not take into account their situatedness since language was long (and still has been, for some) understood as an abstract and hermetic system. It also fails to attend to its social nature, the dialectical forces and the complexity that constitute language and us as we signify and build our own experiences and the world through multiple semiosis and chains of meanings and interpretation (BAKHTIN, 2014), that is, discourse chains that are always imbued with the subjectivity of those who build them. And so, this will constitute plurality and difference in the world.

Additionally, Norton (2013, p. 4) understands subjectivity as derived from the term subject, especially in the sense that individuals constitute 
their identities by occupying different and relative positions as "subject[s] of a set of relationships (i.e. in a position of power) or subject[s] to a set of relationships (i.e. in a position of reduced power)". Norton emphasizes the idea of subjectivity as a site of struggle "as discursively constructed and as always socially and historically embedded" (NORTON, 2013, p. 4).

The Postmodern subject's identity has, therefore, taken on multiple facets, contingent, temporary and even conflicting since each day "the systems of meaning and cultural representation multiply" (HALL, 2011, p. 13). In this same tone, Woodward (2012) emphasizes that such displacements can reconfigure cultural identities that are apparently homogeneous and stable due to the constant interaction between local and global contexts and the historical narratives that constitute them, being neoliberalism and most recently, the pandemic, two great accounts for the present analysis.

Understanding language as the means by which we can represent and translate our thoughts into actions and existence, we can also agree that it is through language that we mark and build "the places from which individuals can position themselves, from which they can speak" (WOODWARD, 2012, p. 18), defining, even if provisionally, their/our identities. According to Hall (2012), the perspective of the sociological subject advances towards an understanding of a dialogical construction process between his social participation and the structures that support his interactions within the environment. In this sense, Hall (2011) defines identity through the metaphor of the subject's sewing to the structures that stabilize him in cultural worlds, which can be temporary, variable and sometimes problematic, marked by history and the subjectivity derived from the meanings we assign to these worlds and relationships, not only by biological factors. As for Menezes de Souza et al. (2019, p. 166), identity should also be described as a fluid and contingent aspect of the self as "[a]ssuming an identity is always a strategy. You use an identity to act in a certain context for a certain purpose".

Referring back to the narratives excerpted above, it is crystal clear how both educators shift identities when it comes to their reflections, predicaments and actions during the pandemic, showing how fluid, complex and fragmented identities can be. As a mom-educator, Luciana is capable of taking action so as to help her children's private school adapt to the transition to virtual/online teaching and learning practices. However, as she feels "safer" and less demanded by her children when it comes to their school lives, which also allows her to carry on with her work at home, at 
the University and as an academic, she also feels that her children are in a privileged position, coming to the point of questioning her choices in terms of her children's education.

Contrarily, Lívia's identity as an academic working at a public Brazilian University is shaken by her strong desire to act through remote interactions with her students, who, even though had once stated their interest in interacting through a blog, end up not showing up for the task for multiple reasons related to technical, emotional and physical restraints. In an attempt to be "proactive" and "accountable" of her salary, to be empathetic with so many teachers who had been keeping up with their work in the midst of the chaos they had been experiencing at home, Livia is faced with neoliberal values - until then strongly criticized in her work (FORTES, 2018) - and subjectivities within her own academic identity. In excerpt 1 she is faced with an identity crisis, corroborating the idea of contradiction and conflict among subjectivities and values that constitute her "self" as in "I have been feeling so powerless and all this pandemic process has even made me consider my choices, motivations and investment as an educator. As a mom, I am ok with the practices I have been observing specially because they have happened and evolved. What kinds of risks am I willing to take? What fights are worth fighting for at home and at work?".

As far as subjectivities are constructed and made visible, it is noticeable from the careful analysis on agency previously presented that both Livia and Luciana, in their own ways, act as "subjects of" actions incited by their willingness to take the actions they believe are needed during such critical times. Additionally, they are also "subject to" dominant discourses and epistemologies, which have been examined critically here (the case of digital epistemologies now "forcefully" present at the private school and the neoliberal ethos on the part of Lívia). However, we can find in Menezes de Souza et al. (2019, p. 163) words of encouragement for such dilemmas as, according to them, "the system that shaped us, and which we are fighting against, is not something out there. Our enemy is not out there. It may be outside, but it is also inside. We have to deal with this duplicity, fight it". The author advocates for a decolonial reasoning in which critique derives from the perception of "us" being "in or with" them, not apart as we are all products of the same unfair systems, resounding Luciana's comment analyzed in the previous section as she perceives her subjected but yet critical self. 
In terms of plurality and difference, Luciana claims that "[i]t seems that we needed to live a pandemic to be more aware of the importance of getting to know the real specificities of our students: their context of living, their identities, subjectivities... Don't we say that Discourses 'construct' us?'. We definitely agree on that as we see that discourses will vary as well as the identities that belong to the Brazilian University contexts, especially after the affirmative actions taken from former governments so as to include underprivileged and non-white people in the academic community (until then, mostly populated by white, upper and middle class citizens). We have seen that as a great social achievement in terms of equity, but how included have these people really been? How anchored and "sewed" are the identities present on campus to subjectivities that constitute the discourses that have been resonated during the pandemic? As Luciana states "Have we been taking their realities into consideration? Or have we just been pretending to do it? Or doing it superficially? The vulnerability and social responsibilities of our students may be constant and not characteristic of the pandemic moment we have been living now". So, has the University really become a site of inclusion and social emancipation in a world that has increasingly valued meritocracy, competition, individuality, efficiency and profit? How unfair can this system be when students' identities and subjectivities are not sewed or anchored to the system, or do not dialogue with the values imposed by the hegemonic discourses of capitalism, liberalism and, mostly, neoliberalism? How much longer will the "misfit" identities resist and survive under such systems?

Speaking of unfair systems, usually, and dialectically, constituted and constitutive of dominant discourses and subjects, we go back to the discussion of how language and institutions operate on the construction of subjectivities and identities. For Woodward (2012), language dialogically operates on people's identities, subjectivities and, therefore, realities as, when meanings are institutionalized, they become of use to a certain group: "There is, among the members of a society, a certain degree of consensus on how to classify things in order to maintain some social order. These shared systems of meaning are, in fact, what is meant by culture" (WOODWARD, 2012, p. 42). According to Bourdieu (2004), this accentuates our inability to perceive characteristics and values that are different from ours and that, consequently, may cause us discomfort for the simple reason that we have not been exposed to models different from ours, implying our enormous 
difficulty in accepting difference. In this sense, the Covid-19 crisis has forced us, public University educators, not only to accept difference in so many ways and under various perspectives - economic, social, cultural, identitary, emotional - but to understand that such differences ought not to be fatalistic, excluding and punitive. This is shown in excerpt 4, when Lívia shares a critical moment denoting how she could have failed to admit that her students had completely different lives - especially when it comes to quarantine times - than hers. And yes, as Luciana points, we needed to live a pandemic to better understand and feel how multiple and complex the identities at the university can be and how immersed we have all been in neoliberalism, leading to (or even, corroborating) Lívia's conflicting observation that academics might be preaching in bubbles that have not aimed, so far, to find some sort of compromise between the neoliberal and the "non-neoliberal" ethos. So, as suggested above and inspired by the work of Bourdieu (1996), could it be possible for us at the University to be accomplices and critical of neoliberalism? Is there any possibility to exchange and learn from both sides of such abyssal lines?

Taking neoliberalism as a hegemonic discourse, not only as an economic policy, but as an ideology and governing rationality (BROWN, 2015) that has strongly influenced the constitution of subjects in the contemporary society, Chun (2013) states that "neoliberalization" shapes subjectivities by representing them economically, constituting, therefore, identities that circulate and that need to be understood and challenged by Applied Linguistics. According to Brown (2015), neoliberalism sees people as human capital (or companies) that must constantly seek ways to increase their value in the present with a view to the future, emphasizing ideals of predictability and meritocracy as, given one's "right" investments, profitable results should be guaranteed. Brown (2015) also points out that if we conceive neoliberalism as a "standardized" reasoning and, therefore, naturalized, regulated and ascending, its influence on practices assumes a dimension of human life, reinforcing the notion of discipline and the docile body of Foucault.

As a consequence of that, Dardot and Laval (2013) claim that subjectivities have been reconstructed and shaped within political, economic, social and subjective conceptions that dialogue with the idea of the entrepreneurial subject and with the absence of the state in the development and provision of public policies that ensure the wellbeing of citizens. It is 
also noted that the commodification of subjectivities has made interpersonal relationships into types of contracts based on efficiency values through discipline and organization techniques (DARDOT; LAVAL, 2013), where predictability, reciprocity and interest are assumed. Besides, the responsibility for such relationships, essentially voluntary, where subjects seem to admit, value and desire such behaviors and subjectivities, is incorporated into their ways of life and thinking, showing a dynamic of subjection to them. For Hilgers (2011), this "individual responsibility" inherent to the discourse of neoliberal subjects leads individuals to become subject to ideal performances, to compete and to be entrepreneurs of themselves, affecting notions of citizenship through subjection technologies, where individual freedom is guided and conditioned by whatever must be acquired "autonomously" and without the state intervention or assistance.

The pandemic unveiled some of these values when it came to the discussions and planning of academic activities during and after quarantine. The interactions around excerpt 3, also commented above in terms of agency, show Luciana's ideal of collectivity and an ethics based on the idea that "no one should be left behind", while Lívia shows a bit of resistance to that idea as she urges to take action no matter how or who could be left behind. Based on her own reflections about the place she occupies as a teacher educator, and, as she sees so many teachers finding their ways to get on with remote teaching, Livia feels compelled to join the transition without further critique, and thus, she takes action by autonomously designing a blog so as to keep interacting with her groups. Beyond being sympathetic, Livia's attitude, seen from a subjection perspective, can reveal plenty of the values attached to this global notion of "individual responsibility" aiming at achieving a certain "ideal performance" as a teacher educator, which, nevertheless, seem to be disconnected from her most immediate academic context, that is, her locality. By challenging herself so as to join the transition to the new virtual classroom, which would eventually come, as we all knew it would, is Livia trying to anticipate something and to evolve as a professor or, is she subjecting to neoliberalization?

Moreover, Lívia feels anxious and guilty as classes took way too long to restart making her feel "unaccountable" and "irresponsible", resounding the neoliberal ethos, even though, up to that moment, the federal government had not designed a plan to provide real digital access to the University community, especially for the underprivileged. Her criticism 
on the slowness of the University might show her lack of sensitivity to perceive the enormous complexity around her. This, in a way, also reflects her desire for efficiency and better governance on the part of the University administration, corroborating neoliberal discourses and governmental practices that have strongly contributed to the dismantling of public institutions in Brazil as she, herself, has witnessed.

Another interaction move worth commenting is Luciana's problematization around the "new" reality teachers have been forced to face and accept as they probably did not have the option not to adhere to remote classes. For her, Lívia's empathy sounds a bit too "romantic" and, we must face it: it really is. Moreover, in terms of neoliberal subjectivities, Livia's sense of "individual responsibility", pointed by Hilgers (2011) above, clashes with the ideal of universal access pursued by public education. Livia thinks she was acting responsibly as a citizen while she subjected to meritocratic and market values inherent to private sector institutions, where teachers have had only one option: to keep their earnings and jobs safe. One more aspect to be highlighted from that interaction is that, as teachers start to feel "safer" with their remote teaching practices, would they be sensing a certain feeling of achievement and success, would they be able to ressignify the subjection as professional development? Can we assume that the change needed for educational practices to keep going on during pandemic times has helped formal education to redesign their traditional and obsolete practices (another point raised by the analysis on agency above)? Once more, can we be complicit and still critical of neoliberalism if we take this perspective into consideration?

The questions are as multiple and diverse as our identities and values can be, corroborating the idea of our subjectivity being a site of struggle. We now come to the end of this analysis, knowing, though, that the matter is far from being settled.

\section{Final thoughts}

One final thought about the pandemic and the narratives we would like to bring relates to our ability to understand that we are all products and makers of history. As products, finding ourselves immersed in hegemonic narratives such as that of neoliberalism, engaging with difference can certainly be an insightful and rich experience. As makers, we can only engage 
with change, if we wish to do so, as long as difference is present to us and we are open to it and to the conflicts that it may engender, as Menezes de Souza puts it "... we have to constantly have what is perhaps the most difficult thing for a human being - the awareness that we can be products of what we are criticizing" (MENEZES DE SOUZA et al., 2019, p. 163).

On top of it, as we have been advocating (FORTES, 2017), inspired by Biesta (2010, 2013), education is a risky "business", and its beauty lies upon the idea that we never know how our beginnings will be taken by the other. So, how risky do we want education to be, or, how willing are we to accept and recognize the so many different identities not only on campus but also within our own selves?

Finally, this duoethnography experience led us both to a great subjectification process. We have learned a lot from this incredibly rich process in various terms as we unveiled presuppositions, assumptions and beliefs that needed to be critically debated through theoretical background and confronted within our own subjectivities and multiple identities, not to mention the epistemologies we have believed in and our praxis as academics. Such “confrontations" have only confirmed Norton's (2013, p. 4) poststructuralist account on identity and subjectivity as "diverse, contradictory, dynamic and changing over historical time and social space". In that sense, our identities can be seen and felt as real "sites of struggle" and should be constantly changing and adjusting to more or less powerful (and hegemonic) discourses as we engaged in (critical) meaning-making processes through the narratives we exchange(d), which should help us organize and reorganize a sense of who we are and how we relate to the reality around us. As Menezes de Souza et al. (2019, p. 164) suggest,

[c] ollaboration is joining without erasing differences, that is, it is not reproducing, it is producing something different from what I knew, from what she knew, and something that will not reproduce what each of us already knew, because it is something new. And this new something that we help to produce will lead us to new learning.

Our collaboration process as writers, academic and life partners was one of joy and conflict, which has, nevertheless, led us to great new beginnings that will certainly contribute to our personal and professional lives. We hope to have collaborated with the reader and with the Applied Linguistics field so that we can all benefit from new learnings. 


\section{Authors' contributions}

The present four-handed work submitted to Revista Brasileira de Linguistica Aplicada was conceived and written by the authors Livia Fortes and Luciana Ferrari, colleagues at the Department of Languages and Literature at the Federal University of Espirito Santo (UFES). The text was entirely written in a collaborative and dialogical manner, from its very embryonic stages to the very final revisions, which certainly embodies the research methodology we have adopted, discussed and presented above. Further detail is provided in the text.

\section{References}

ARENDT, H. A condição bumana. Trad. Roberto Raposo, revisão de Adriano Correia. Rio de Janeiro: Forense Universitária, 2014.

BAKHTIN, M. Marxismo e filosofia da linguagem. 16. ed. São Paulo: Hucitec, 2014.

BHABHA, H. On Being Unprepared (For Our Own Times). Oxford: The Oxford Research Center in the Humanities, 2020. Available at: https://torch.ox.ac.uk/ event/live-event-in-conversation-with-homi-bhabha. Accessed on: March 7, 2020.

BIESTA, G. J. J. Good Education in an Age of Measurement; Ethics, Politics, Democracy. Boulder, CO: Paradigm Publishers, 2010.

BIESTA, G. J. J. The Beautiful Risk of Education. London: Paradigm Publishers, 2013.

BIESTA, G. J. J. Cultivating Humanity or Educating the Human? Two Options for Education in the Knowledge Age. Asia Pacific Education Review, Seoul, v. 15, p. 13-19, 2014. DOI: https://doi.org/10.1007/s12564-013-9292-7

BOURDIEU, P. A Economia das Trocas Linguísticas: o que falar quer dizer. São Paulo: Edusp, 1996.

BOURDIEU, P. A Economia das trocas simbólicas. 5. ed. São Paulo: Perspectiva, 2004. BROWN, W. Undoing the Demos: Neoliberalism's Stealth Revolution. Cambridge, MA: MIT Press, 2015. DOI: https://doi.org/10.2307/j.ctt17kk9p8

CASTELLS, M. A Sociedade em rede. São Paulo: Paz e Terra, 1999.

CHUN, C. The "Neoliberal Citizen": Resemiotizing Globalized Identities in EAP Materials. In: GRAY, J. (ed.). Critical Perspectives on Language Teaching Materials. Hampshire, England: Palgrave Publishers, 2013. DOI: https://doi. org/10.1057/9781137384263_4 
COPE, B.; KALANTZIS, M. (ed.). Multiliteracies: Literacy Learning and the Design of Social Futures. London: Routledge, 2000.

DARDOT, P.; LAVAL, C. The New Way of the World: On Neoliberal Society. New York: Verso, 2013.

ERICKSON, F. Qualitative Methods in Research on Teaching. In: WITTROCK, M. C. (ed.). Handbook of Research on Teaching. London: McMillan Publishing Company, 1986.

FAIRCLOUGH, N. Discourse and Social Change. Cambridge, MA: Polity, 1992.

FREIRE, P. Pedagogia do oprimido. 17. ed. Rio de Janeiro: Paz e Terra, 1987.

FORTES, L. "Ser ou não ser": questões sobre subjetividade e o ensino de inglês na escola pública. 2017. 233f. Tese (Doutorado em Estudos Linguísticos e Literários em Inglês) - Faculdade de Filosofia, Letras e Ciências Humanas, Universidade de São Paulo, São Paulo, 2017.

FORTES, L. Ressignificando o ensino (descontextualizado) de língua inglesa na escola pública: letramentos, engajamento e subjetificação. PERcursos Linguísticos, Vitória, v. 8, n. 20, p. 132-152, 2018.

GEE, J. P. Social Linguistics and Literacies: Ideologies in Discourses. 4. ed. London, UK: Routledge, 2012.

HALL, S. A identidade cultural na Pós-Modernidade. 11. ed. Rio de Janeiro: DP\&A Editora, 2011.

HALL, S. Quem precisa de identidade? In: SILVA, T. T. (org.). Identidade e diferença: a perspectiva dos estudos culturais. 12. ed. Petrópolis, RJ: Vozes, 2012.

HILGERS, M. The Three Anthropological Approaches to Neoliberalism. UNESCO. Malden, Massachusetts, USA: Blackwell Publishing, 2011.

KRESS, G. Literacy in the New Media Age. London: Routledge, 2003. DOI: https:/ / doi.org/10.4324/9780203299234

LANKSHEAR, C.; KNOBEL, M. Critical Literacy and Active Citizenship. In: MUSPRATT, S.; LUKE, A.; FREEBODY, P. (ed.). Constructing Critical Literacies. New Jersey: Hampton Press, 1997.

LANKSHEAR, C.; KNOBEL, M. New Literacies: Changing Knowledge and Classroom Learning. New York: Open University Press, 2003.

LOWE, R.; KICZKOWIAK, M. Native-Speakerism and the Complexity of Personal Experience: A Duoethnographic Study. Cogent Education, [S.l.], v. 3, n. 1, Art. 1264171, 2016. DOI: https://doi.org/10.1080/2331186X.2016.1264171 
MENEZES DE SOUZA, L. M. Para uma redefinição de Letramento Crítico: conflito e produção de significação. In: MACIEL, R. F; ARAÚJO, V. A. (org.). Formação de Professores de Linguas: ampliando perspectivas. Jundiaí: Paco Editorial, 2011.

MENEZES DE SOUZA, L. M. T. et al. Parceria acadêmica e esperança equilibrista: uma conversa com Lynn Mario Trindade Menezes de Souza. Pensares em Revista, São Gonçalo-RJ, n. 15, p. 162-172, 2019. DOI: https://doi.org/10.12957/ pr.2019.41967

MORGAN, B.; MARTIN, I.; MACIEL, R. F. The Walkyria Effect: Inspiring Transnational Language Teacher Education. Pensares em Revista, São Gonçalo-RJ, n. 15, p. 8-21, 2019. DOI: https://doi.org.10.12957/pr.2019.41188

NORTON, B. Identity and Language Learning: Extending the Conversation. 2. ed. Bristol: Multilingual Matters, 2013. DOI: https://doi.org/10.21832/9781783090563 ROSE, H.; MONTAKANTIWONG, A. A Tale of Two Teachers: A Duoethnography of the Realistic and Idealistic Successes and Failures of Teaching English as An International Language. RELC Journal, [S.l.], v. 49, n. 1, p. 88-101, 2018. DOI: https://doi.org/10.1177/0033688217746206. Available at: https:// journals.sagepub.com/doi/10.1177/0033688217746206. Accessed: Jun. 26, 2020. SAWYER, R. D.; LIGGETT, T. Shifting Positionalities: A Critical Discussion of a Duoethnographic Inquiry of a Personal Curriculum of Post/Colonialism. International Journal of Qualitative Methods, [S.l.], v. 11, n. 5, p. 628-651, Dec., 2012. DOI: https://doi.org/10.1177/160940691201100507.

SOUSA SANTOS, B. Para além do pensamento abyssal: das linhas globais a uma ecologia de saberes. In: SANTOS, B. S.; MENESES, M. P. (org.). Epistemologias do Sul. São Paulo: Cortez, 2010.

WOODWARD, K. Identidade e diferença: uma introdução teórica e conceitual. In: SILVA, T. T. (org.). Identidade e diferença: a perspectiva dos estudos culturais. 12. ed. Petrópolis, RJ: Vozes. 2012.

Data de submissão: 22/8/2020. Data de aprovação: 16/2/2021. 